\title{
Phosphorus Speciation in Coal Bottom Ash
}

\author{
Firat Aydin ${ }^{a}$, Abdurrahman Saydut $^{\mathrm{b} *}$, Isil Aydin ${ }^{\mathrm{a}}$, and Candan Hamamci ${ }^{\mathrm{a}}$ \\ a Dicle University, Science Faculty, Chemistry Department \\ TR-21280 Diyarbakir, Turkey \\ b Dicle University, Engineering Faculty, Mining Engineering Department \\ TR-21280 Diyarbakir, Turkey
}

\section{INTRODUCTION}

Worldwide, approximately 500 million tons of coal ashes are produced annually, most of which are transferred to landfills and surface impoundments. However, there is a growing interest in coal ash utilization, particularly in waste management, because coal ashes are often used as a sorbent for various pollutants such as toxic heavy metals, especially in water. Coal ashes have significant retention capacity for various contaminants $(\mathrm{Cd}, \mathrm{Pb}, \mathrm{Hg}$, $P$, etc.) ranging from anions and cations to dissolved organic compounds (1).

Coal, coal bottom ash, and coal fly ash contain many elements that are mobilized during coal burning which may be released either in the ash particles or in the gaseous state (2). Coal is a heterogeneous material whose physical and chemical properties are relatively difficult to determine. It usually contains a significant amount of different inorganic and organic impurities (Mo, $\mathrm{V}, \mathrm{Ni}, \mathrm{U}, \mathrm{S}$, organo metallic compands, thiols) that could cause environmental problems (corrosion; health effects; air, water, and soil pollution) (3, 4). High-quality coal reserves in the world are gradually being depleted and, therefore, there is a growing interest in using the inferior grades of coal which usually contain high ash, sulfur, and hazardous trace elements (5-8). Analysis of the inorganic chemical composition of coal reveals infor-

\footnotetext{
*Corressponding author

E-mail: saydut@dicle.edu.tr

Tel.: +904122488403

Fax: +904122488389
}

\begin{abstract}
Coal, coal bottom ash (CBA), and coal fly ash contain many elements in different forms which may change during the coal combustion process. A true understanding of the dynamics of phosphorus $(\mathrm{P})$ in the natural environment requires an expanded knowledge of its oxidation-reduction (redox) cycling. This study presents a sequential extraction method for the speciation of phosphorus from CBA in seven forms and their determination by inductively coupled plasma optical emission spectrometry (ICP-OES).

The total $\mathrm{P}$ concentration in CBA was found to be $651.48 \mathrm{mg}$ $\mathrm{kg}^{-1}$. The most abundant form of $\mathrm{P}$ in CBA is the sulfide fraction of $\mathrm{P}(40.42 \%)$. The relative abundances of the remaining $P$ fractions follow the order: Residual $38.63 \%>$ Reducible $15.12 \%>$ Carbonate $3.42 \%>$ Oxidizable $1.10 \%$ > Exchangeable $0.94 \%>$ Water soluble $0.37 \%$.
\end{abstract}

mation about the depositional environment, as well as the sources and differential fixations of the elements during the coalification processes $(9,10)$. The hazardous trace elements, such as heavy metals, in coal are of considerable concern with regard to environmental and health safety. Some of these hazardous elements $(\mathrm{Ni}, \mathrm{Hg}, \mathrm{Pb})$ are released from the coal into the air, while others (Mo, V, Cd, Cu, Co, $\mathrm{Cr}$, etc.) are released from CBA and coal fly ash. These elements enter the environment mostly from nat- ural sources such as water, air, dust, soil, food, mining tailings, earth crust, volcanic eruptions, sewage sludge, sediments, animal manure, marshes, landfills, and also from the burning of fossil fuels. Indeed, it has been reported that uncontrolled disposal of coal ashes may cause a dispersion of fine particles (into the air, soils, food, water) and become hazardous to health (11-13).

Phosphorus is found in nature in various forms including (a) mineral forms; (b) organic forms such as phospholipids, nucleic acids, proteins, polysaccharides, nucleotide cofactors, and as phosphonates; (c) dissolved inorganic forms such as pentavalent, trivalent, or univalent dissolved species; (d) gaseous forms in the -III oxidation state; and (e) particulate or colloidal forms. Its current abundance in the earth's crust is approximately $0.12 \%$. However, almost all of the phosphorus on Earth is found in the form of minerals including apatites (chloro and fluoro), vivianite, wavellite, and phosphorites. Phosphorus is taken up by plants in water-soluble form as $\mathrm{H}_{2} \mathrm{PO}_{4}^{-}$, $\mathrm{HPO}_{4}{ }^{2-}$, and $\mathrm{PO}_{4}{ }^{3-}$. Phosphate fertilizers are essentially used in agriculture to supply nutrients for growing plants. In addition, phosphate is an important constituent in animal feed stock, is used in the food industry, and in other chemical industries (14). Phosphates $[\mathrm{P}(\mathrm{V})]$, the most abundant form of phosphorus in the environment by nature, are readily assimilated aerobically and have for this reason been traditionally used as fertilizers. Phosphine, $\mathrm{PH}_{3}$, is a poisonous gas. Organophosphorus compounds are 
highly toxic, having the effect of anticholinesterase. These compounds are used to synthesize agricultural insecticides and for chemical warfare. Phosphonates correspond to anions of phosphonic acid and are similar to phosphates, except that they have a carbonphosphorus bond (C-P) instead of the carbon-oxygen-phosphorus (C-O-P) linkage. The molecule type is R-PO $(\mathrm{OH})_{2}$. Phosphonates are highly water-soluble, poorly soluble in organic solvents, and are not volatile. They have a resistance to chemical hydrolysis and thermal descomposition, are chemically stable making possible their use as detergents, plasticizers, coolant additives, pesticides, and chelating agents in many industrial applications through their ability to form strong complexes with metals. Phosphonates can enter the environment as pollution from industrial activities in large amounts (15).

Since phosphorus is available in many forms, speciation is of great importance because the oxidation state influences both mobility and toxicity. The analytical speciation of phosphorus is necessary to understand its mechanisms of transport and thus its environmental impact. Speciation analysis is defined by the IUPAC (International Union of Pure and Applied Chemistry) as analytical activities concerned with identifying and/or measuring the quantities of one or more individual chemical species in a sample. The definition of species is based on several different levels of atomic and molecular structures where chemical forms of the same element are manifest. The differences can be considered at the level of (a) isotopic composition, (b) electronic or oxidation state, (c) inorganic and organic compounds and their complexes, (d) organ metallic species, and (e) macromolecular compounds and complexes (16-19).
Optical methods based on molecular spectroscopy techniques (visible photometry, thermal lens spectroscopy, chemiluminiscence and fluorescence), atomic spectroscopic techniques (atomic absorption spectrometry, inductively coupled plasma-atomic emission spectrometry) and electrochemical techniques (potentiometry, amperometry and voltammetry) are the usual method for $\mathrm{P}$ speciation. Chromatographic methods such as high-performance liquid/ion chromatography, gel filtration/exclusion chromatography and capillary electrophoresis together with the use of several detection systems have enabled carrying out speciation (20). However, non- chromatographic methods of elemental speciation analysis offer a cheaper, simpler and, in general, more sensitive alternative than the use of chromatographic systems. Nowadays, the combination of chromatography (in its various modes) and the sensitive spectroscopic detection methods has coalesced into hyphenated techniques (21).

Non-chromatographic methodologies based on chemical speciation are still growing because they can offer simple and inexpensive ways to enable speciation or, at least, the determination of specific or toxic forms of trace elements. The advantages of non-chromatographic speciation analysis procedures include (a) low cost due to the use of just an atomic or ionic spectrometric technique without the need of the chromatographic system, (b) use of less sample than is required for chromatographic analysis, and (c) an increase in sensitivity, because chromatographic dispersion is avoided and species extracts can be directly measured with the single limitations of the species concentration and sample volume. Additionally it must be noted that some of the non-chromatographic strategies also involve a species separation which can improve their preconcentration $(21,22)$.

Several methods have been considered for the extraction of elemental species in biological and environmental samples. They are classified according to solvent polarity and acidity, the aid of chelating agents, and the use of enzymatic hydrolysis. In addition to classical solvent extraction techniques [liquid-liquid extraction (LLE)], one must consider solid phase extraction (SPE), solid phase microextraction (SPME), singledrop microextraction (SDME), supercritical fluid extraction (SFE), accelerated solvent extraction (ASE), and other extraction methods that offer new possibilities for speciation analysis (23).

A wide variety of sequential extraction methods have also been employed by researchers (16-19, 24-28).

The aim of this research was to investigate the total and distribution of $\mathrm{P}$ (water-soluble, exchangeable, carbonate, reducible, oxidizable, sulfide, and residual fractions) in coal bottom ash using ICP-OES analysis. This report is the first in using the method for the speciation of $\mathrm{P}$ in CBA. This method is very attractive, easy to use, faster, and offers significant speciation information at lower cost and higher sample throughput.

\section{EXPERIMENTAL}

\section{Instrumentation}

A Model Optima ${ }^{\mathrm{TM}} 2100 \mathrm{DV}$ inductively coupled plasma optical emission spectrometer (ICP-OES) (PerkinElmer, Inc., Shelton, CT, USA) was used to determine the different phosphorus forms. The instrumental conditions were optimized to obtain sufficient sensitivity and precision (see Table I). The spectral wavelength selected for the phosphorus analyses was $213.617 \mathrm{~nm}(14,29)$. 


\section{Reagents and Standard Solutions}

The reagents used were of Suprapur ${ }^{\circledR}$ grade (Merck \& Co., Darmstadt, Germany) when available or of analytical grade and used without further purification. Deionized water, obtained with a Milli$\mathrm{Q}^{\mathrm{TM}}$ system (Millipore Corporation, Bedford, MA, USA), was used throughout this study.

A solution of $1000 \mathrm{mg} \mathrm{L}^{-1} \mathrm{P}$ was prepared from $\mathrm{KH}_{2} \mathrm{PO}_{4}$ (Fluka, Heidelberg, Germany). The calibration standard solutions used were made by appropriate dilution of the stock standards.

Standard reference material (SRM) NIST 1632c Bituminous Coal was used to check the accuracy of the proposed analytical method (National Institute of Standards and Technology Gaithersburg, MD, USA).

\section{Sample Preparation}

Coal samples were obtained from imported Russian coal used in Turkey. A sample amount of about $10.0 \mathrm{~g}$ was oven-dried (Memmert ULM 500) at $105^{\circ} \mathrm{C}$, the sample was crushed with a jaw breaker (Model Retsch BB1/A, Haan, Germany) and ground in a rotor beater mill (Retsch SRZ). The particle sizes of the samples were sifted to less than $250 \mu \mathrm{m}$. The reference material was dried in an oven at $105^{\circ} \mathrm{C}$ for 3 hours and stored until analysis over silicagel in a desiccator. For analysis, $10.0 \mathrm{~g}$ samples were put into a porcelain crucible and subjected to a calcination step in a muffle furnace at $650{ }^{\circ} \mathrm{C}$ for about 8 hours (13).

\section{Sequential Extraction Procedure}

The method is based on sequential extractions of $P$ of coal bottom ash, releasing seven forms of phosphorus: water-soluble, exchangeable, carbonate, reducible, oxidizable, sulfide, and residual.

TABLE I

ICP-OES Operating Conditions

\begin{tabular}{lr}
\hline Parameters & \\
\hline RF power & $1450 \mathrm{~W}$ \\
Plasma gas flow rate & $15 \mathrm{~L} \mathrm{~min}^{-1}$ \\
Auxiliary gas flow rate & $0.2 \mathrm{~L} \mathrm{~min}^{-1}$ \\
Nebulizer gas flow rate & $0.8 \mathrm{~L} \mathrm{~min}^{-1}$ \\
Sample flow rate & $1.5 \mathrm{~L} \mathrm{~min}^{-1}$ \\
View mode & Axial-Radial \\
Read & Peak area \\
Source equilibration time (s) & $15 \mathrm{~s}$ \\
Read delay (s) & $60 \mathrm{~s}$ \\
Replicates & 3 \\
Background correction & S-point (manual point correction) \\
Spray chamber & Scott type spray chamber \\
Nebulizer & Cross-Flow GemTip Tebulizer \\
Detector & (HF resistant) \\
Purge gas & CCD \\
Shear gas & Nitrogen \\
Gas & Air \\
Analytical wavelength & Argon \\
\hline
\end{tabular}


$2 \mathrm{~mL}$ of $2 \mathrm{~mol} \mathrm{~L}^{-1} \mathrm{NH}_{4} \mathrm{OAc}$ in $20 \%$ $\mathrm{HNO}_{3}(\mathrm{v} / \mathrm{v})$ was added, the sample diluted and brought to $25-\mathrm{mL}$ volume with deionized water, and agitated continuously for 30 minutes.

(f) Sulfide fraction:

The residue from (e) was digested with $20 \mathrm{~mL}$ of aqua regia $(3 \mathrm{HCl}+$ $1 \mathrm{HNO}_{3}$ ) at $120^{\circ} \mathrm{C}$ on a hot plate for 4 hours with continuous shaking. The extract was filtered, diluted, and brought to $25-\mathrm{mL}$ volume with deionized water.

(g) Residual:

The residue from (f) was digested by adding a mixture of $\mathrm{HNO}_{3}, \mathrm{HF}$, and $\mathrm{HCl}$. First, $10 \mathrm{~mL}$ of $\mathrm{HNO}_{3}$ was added to the residue, gently heated on a hot place and evaporated on a sand bath (150-160 ${ }^{\circ} \mathrm{C}$ ) to 1-2 mL. After cooling, $10 \mathrm{~mL}$ of $\mathrm{HF}$ was added and slowly evaporated to dryness at room temperature. The residue was dissolved by adding $2 \mathrm{~mL}$ of $\mathrm{HCl}$, heated on a hot plate to $150-160^{\circ} \mathrm{C}$ for 2 hours, then $10 \mathrm{~mL}$ of deionized water was added, heated to $150-160^{\circ} \mathrm{C}$ again for 2 hours, then filtered into a 50-mL volumetric flask. The mixture was rinsed with deionized water three times. Then the sample was made up to $25-\mathrm{mL}$ volume with deionized water.

Approximately $2 \mathrm{~g}$ of coal bottom ash sample was dissolved in a 10-mL mixture of perchloric (70\%) and sulfuric acid (98\%) (1:1). Following filtration, total phosphorus was determined using ICP-OES (13, 14, 16, 17).

\section{RESULTS AND DISCUSSION}

The total $\mathrm{P}$ concentration in the coal bottom ash sample that will leach out using the described sequential extraction conditions was obtained from the six $(a-f)$ sample fractions listed in the previous paragraph. Ash, the inorganic residue derived from the burning of coal, represents the noncombustible impurities originally present in coal. Phosphorus is an element also contained in airborne particulates originating from fossil fuel combustion (30). Investigation of the sources of $\mathrm{P}$ in geological matrices indicates that there is an increased awareness of its potential health hazards from environmental pollution (28). Although the total concentration of $P$ is still useful in many areas, the knowledge of speciation is of primary importance because the toxicity, mobility, bioavailability, and bioaccumulation depend on the chemical species (22). Both agronomic and environmental aspects should be taken into consideration when evaluating the extractable $P$ results (31).

The amount of phosphorous that is naturally present in food varies considerably but can be as high as $370 \mathrm{mg} / 100 \mathrm{~g}$ (in liver) or low (as in vegetable oils). Foods rich in phosphorous include tuna, salmon, sardines, liver, turkey, chicken, eggs, and cheese (200 g/100 g). Phosphate is a dietary requirement, and the recommended intake is $800 \mathrm{mg} /$ day. A normal diet provides between 1000 and $2000 \mathrm{mg} /$ day, depending on the phosphate-rich foods consumed. Too much phosphate can cause health problems, such as kidney damage and osteoporosis.

Phosphorus is determined using a wide variety of techniques, including gravimetric and volumetric methods, ion chromatography (IC), and various spectrometric techniques such as X-ray fluorescence (XRF), atomic absorption spectrometry (AAS) (24), inductively coupled plasma optical emission spectrometry (ICP-OES), inductively coupled plasma mass spectrometry (ICP-MS), and UV (32, 33). The two crucial parameters in all analytical chemical procedures are sensitivity and selectivity. The most simple and reliable analytical methods for the elemental analysis of phosphate rock are provided by using ICP-OES due to its high selectivity and low interference problems. The $213.617 \mathrm{~nm}$ wavelength was used in this study. Although the intensity of P emission is not as high at this wavelength, it offers better detectability (signal to background ratio) and was free from major spectral interferences such as $\mathrm{Mo}, \mathrm{V}, \mathrm{Cr}, \mathrm{Ti}, \mathrm{Al}, \mathrm{Zr}$, and $\mathrm{Hf}$. The choice of emission line, low sensitivity, and refractoriness are among the difficulties reported in the determination of $P$ in rock by atomic emission spectroscopy. Suitable lines reported (free from spectral interferences) are $214.914 \mathrm{~nm}$ for direct current plasma (DCP); $178.287 \mathrm{~nm}, 213.618 \mathrm{~nm}, 214.914$ $\mathrm{nm}$, and $253.565 \mathrm{~nm}$ for the ICP $(20,34)$. Optimum line selection for trace analysis implies choosing the prominent lines with minimum value of the true detection limit, i.e., those with lowest line interference and background (wing) interference signals in the presence of the matrix $(20,35)$.

The conventional method of Sanei et al. (24), with modification was used for the sequential extraction. CBA samples were subjected to a 7-step sequential extraction experiment. The total $\mathrm{P}$ content of all phases was compared with the certified values and with the values obtained from the total digestion. The certified and experimental results are listed in Table II and, as can be seen, there is good agreement. Table III lists the total $\mathrm{P}$ and individual $\mathrm{P}$ species concentrations. The total $\mathrm{P}$ concentration in CBA was found to be $651.48 \mathrm{mg} \mathrm{kg}^{-1}$. The most abundant form of $\mathrm{P}$ in CBA is the sulfide fraction of $\mathrm{P}$ (40.42\%). The relative abundances of the remaining $\mathrm{P}$ fractions follow the order: Residual 38.63\% > Reducible $15.12 \%>$ Carbonate $3.42 \%>$ Oxidizable $1.10 \%>$ Exchangeable $0.94 \%>$ Water soluble $0.37 \%$. 
Inorganic $\mathrm{P}$ can exist in five different oxidation states $(+\mathrm{V},+\mathrm{III},+\mathrm{I}$, $0,-$ III). A true understanding of the dynamics of $P$ in the natural environment requires expanded knowledge of its oxidation-reduction (redox) cycling. Phosphite is stable in the absence of strong oxidizing agents and its salts are relatively soluble. Thus, it may have accumulated on the primitive Earth, where ultraviolet irradiation of solutions of phosphite in the presence of simple organic compounds (e.g., acetylene) leads to the synthesis of water-soluble polyphosphonic acids [e.g., methyl and ethyl phosphonic acids, vinyl phosphonic acid (VPA)]. It is commonly assumed that phosphorus occurs almost exclusively in the environment as fully oxidized phosphate (primarily $\mathrm{H}_{2} \mathrm{PO}_{4}{ }^{-}$and $\mathrm{HPO}_{4}{ }^{2-}$, where the oxidation state of phosphorus is $+\mathrm{V}$ ). Recent developments in the field of microbiology and research on the origin of life have suggested a possibly significant role for reduced, inorganic forms of phosphorus in bacterial metabolism and as evolutionary precursors of biological phosphate compounds. Reduced inorganic forms of phosphorus include phosphorus acid $\left(\mathrm{H}_{3} \mathrm{PO}_{3}\right.$, $\mathrm{P}(+\mathrm{III})$ ), hypophosphorus acid $\left(\mathrm{H}_{3} \mathrm{PO}_{2}, \mathrm{P}(+\mathrm{I})\right)$ and various forms of phosphides (P(-III)). Phosphides or $P$ compounds in the $P(-$ III) state are the most widely discussed forms of reduced $P$ found in the literature. Phosphine is formed naturally during the anaerobic decomposition of organic matter (i.e., splitting of proteins) containing $\mathrm{P}$ (36). If reduced $P$ is significant, then the evidence for these species in the environment will help expand the simplified reduced $P$ cycle and redefine the global biogeochemical cycle for $\mathrm{P}$ to include reduced $P$.

Phosphite and hypophosphite applied as fertilizers or pesticides/ herbicides have been detected in anaerobic sediments (a highly organic sediment formed in the absence or near absence of oxygen in water that is rich in hydrogen sulfide), sewage treatment works, and in industrial and agricultural processes. In the past, large-point sources (primarily industrial) were the focus of $\mathrm{P}$ pollution prevention. Biomonitoring of phosphorus is becoming very important and much

TABLE II

Accuracy Assessment of the Analysis of Coal Standard Reference Material : NIST SRM 1632c $\left(\mu \mathrm{g} \mathrm{g}^{-1}\right.$, dry wt.)

\begin{tabular}{lcc}
\hline Element & Certified & ICP-OES Found \\
\hline $\mathrm{P}$ & $94.8\left(\mu \mathrm{g} \mathrm{g}^{-1}\right)$ & $93.9 \pm 0.52\left(\mu \mathrm{g} \mathrm{g}^{-1}\right)$ \\
\hline
\end{tabular}

TABLE III Concentration of Total $P$ and $P$ Species in Coal Bottom Ash

\begin{tabular}{lrr}
\hline P & $\mathrm{C}\left(\mathrm{mg} \mathrm{kg}^{-1}\right)$ & W (\%) \\
\hline Total & 651.476 & 100.00 \\
Sulfide fraction & 263.300 & 40.42 \\
Residual & 251.700 & 38.63 \\
Reducible fraction & 98.500 & 15.12 \\
Carbonate fraction & 22.260 & 3.42 \\
Oxidizable fraction & 7.180 & 1.10 \\
Exchangeable fraction & 6.131 & 0.94 \\
Water soluble & 2.405 & 0.37 \\
\hline
\end{tabular}

progress has been made in controlling $\mathrm{P}$ discharge from industrial operations and the contribution from non-point sources such as agricultural soils and surface waters (36).

\section{CONCLUSION}

Phosphorus $(\mathrm{P})$ is an element found in airborne particulates originating from fossil fuel combustion, particularly coal. In this study, speciation of $\mathrm{P}$ in coal bottom ash is performed using inductively coupled plasma optical emission spectrometry (ICP-OES). The 213.617-nm line was used because it offers better detectability (signalto-background ratio) and was free from major spectral interferences. The method is based on the sequential extraction of $P$ in seven forms: water-soluble, exchangeable, carbonate, reducible, oxidizable, sulfide, and residual.

Phosphorus was sequentially leached in seven extraction solutions: water, $1 \mathrm{M} \mathrm{MgCl}_{2} \cdot 6 \mathrm{H}_{2} \mathrm{O}, 1 \mathrm{M}$ $\mathrm{NaAc}, 0.1 \mathrm{M} \mathrm{NH}_{2} \mathrm{OH} \cdot \mathrm{HCl}$ at $25 \%$ (v/v) $\mathrm{CH}_{3} \mathrm{COOH}, \mathrm{H}_{2} \mathrm{O}_{2}$, aqua regia, and $\mathrm{HF}-\mathrm{HCl}-\mathrm{HNO}_{3}$. The total $\mathrm{P}$ concentration in CBA was found to be $651.48 \mathrm{mg} \mathrm{kg}^{-1}$. The most abundant form of $\mathrm{P}$ found in CBA is the sulfide fraction of $\mathrm{P}(40.42 \%)$. The relative abundances of the remaining $\mathrm{P}$ fractions follow the order: Residual 38.63\% > Reducible $15.12 \%>$ Carbonate $3.42 \%>$ Oxidizable $1.10 \%>$ Exchangeable $0.94 \%>$ Water-soluble $0.37 \%$. The advantages of the technique include a high degree of automation, good reproducibility, and short analysis time and thus make it the method of choice for the speciation of phosphorus.

Received May 19, 2011. 


\section{Appectroscopy \\ 1 Vol. 32(5), Sept./Oct. 2011}

\section{REFERENCES}

1. J. Yan, D.W. Kirk, C.Q. Jia, X. Liu, J. Hazard. Mater. 148, 395 (2007).

2. H. Lachas, R. Richaud, K.E. Jarvis, A. A. Herod, D.R. Dugwell, and R. Kandiyoti , Analyst 124, 177 (1999).

3. M. Z. Duz, Y. Tonbul, A. Baysal, O Akba, A. Saydut, and C. Hamamci, J. Therm. Anal. Calorim. 81, 395 (2005).

4. S. Erdogan, A. Baysal, O.Akba, and C.Hamamci, Pol. J. Environ. Stud. 16(5), 671 (2007)

5. C. Hamamci, F. Kahraman, and M. Z. Duz, Fuel Process. Technol. 50, 171 (1997).

6. P. Balaz, R. B. La Count, D. B. Kern, and L. Turcaniova, Fuel 80, 665 (2001).

7. A. Saydut, M. Z. Duz, and C. Hamamci, Oil Shale 24(3), 476 (2007).

8. M. Z. Duz, A. Saydut, S. Erdogan, and C. Hamamci, Energ. Explor. Exploit. 27(6), 391 (2009).

9. I. Rodushkin, M. D. Axelsson, and E. Burman, Talanta 51, 743 (2000).

10. A. Saydut, M. Z. Duz, I. Aydin, and C. Hamamci, Energ. Explor. Exploit. 26, 133 (2008).

11. M. Paul, M. Seferinoglu, G. A. Aycik, A. Sandstrom, M. L. Smith, and J. Paul, Int. J. Miner. Process. 79(1), 27 (2006).

12. A. Saydut, Y. Tonbul, A. Baysal, M. Z. Duz, and C. Hamamci, J. Sci. Ind. Res. India 66(1), 72 (2007).

13. A. Saydut, Energ. Explor. Exploit. 28(2), 105 (2010).

14. I. Aydin, F. Aydin, A. Saydut, E. G. Bakirdere, C. Hamamci, Microchem. J. 96, 247, (2010).

15. B. Fuentes, M. de la Luz Mora, N.S. Bolan and R. Naidu, Developments in Soil Science, 32, 363 (2008).

16. I. Aydin, F. Aydin, A. Saydut, and C. Hamamci, J. Hazard. Mater. 168, 664 (2009)

17. I. Aydin, S. Imamoglu, F. Aydin, A. Saydut, and C. Hamamci, Microchem. J. 91(1), 63 (2009).
18. B. Gunduz, I. Aydin, S. Bakidere, A. Saydut, F. Aydin, Atom. Spectrosc. 31(6), 196 (2010).

19. B. Gunduz, F. Aydin, I. Aydin, C. Hamamci, Microchem. J. 98 (1) 72 (2011).

20. J.M. Estela, and V. Cerda, Talanta, 66, 307 (2005)

21. A. Gonzalvez, M.L. Cervera, S. Armenta, M. de la Guardia Anal. Chim. Acta 636, 129 (2009).

22. A. Gonzalvez, S. Armenta, M.L. Cervera, M. de la Guardia, Trends in Anal. Chem., 29, 260 (2010).

23. M.A. Vieira, P. Grinberg, C.R.R. Bobeda, M.N.M. Reyes, and R.C. Campos, Spectrochim. Acta, Part B 64, 459 (2009)

24. H. Sanei, F. Goodarzia, and E. V. D. Flier-Keller, J. Environ. Monit. 3, 27 (2001).

25. J. F. Oxmann, Q.H. Pham, R.J. Lara, Eur J Soil Sci, 59, 1177 (2008).

26. W. Solomons, and U. Forstner, Environ. Technol. Lett., 1, 506 (1980).

27. A. Tessier, P.G.C. Campbell, and M. Bisson, Anal. Chem., 51, 844 (1979).

28. A.K. Das, R. Chakraborty, M. L. Cervera, and M. De la Guardia, Talanta 71, 987 (2007).

29. B. Gumgum, C. Hamamci, Spectroscopy Letters 9, 1229 (1991).

30. S. Kawakubo, S. Hashi, and M. Iwatsuki, Wat. Res. 35(10), 2489 (2001).

31. D. Pizzeghello, A. Berti, S. Nardi, and F. Morari, Agr. Ecosyst. Environ. 141,58 (2011).

32. B.Welz, F.G. Lepri, R.G.O. Araujo, S.L.C. Ferreira, M.D. Huang, M. Okruss, and H. B.Ross, Anal. Chim. Acta. 647, 137 (2009).

33. K. Pyrzynska, Anal. Chim. Acta. 590, 40 (2007)

34. M.A. Marina, and M.C.B. Lopez Anal. Chim. Acta, 432, 157 (2001).

35. N. Daskalova, S. Velichkov, P. Slavova, E. Ivanova, and L. Aleksieva, Spectrochim. Acta Part B, 52 257 (1997).

36. G. Hanrahan, T.M. Salmassi, C.S. Khachikian, and K.L. Foster, Talanta, 66, 435 (2005). 